\title{
Uzman Görüşleri Bağlamında Haber Üretiminde Otomatikleşme: Robot Gazetecilik
}

\author{
Bilge Narin \\ araştırma görevlisi doktor, gazi üniversitesi iletişim fakültesi \\ tübitak doktora sonrası araştırma bursiyeri \\ umass amherst, department of communication \\ narinbilge@gmail.com
}

\section{Abstract \\ Automation of News Production in the Context of the Opinions of the Experts: Robot Journalism}

The developments in internet technologies not only affect the distribution and consumption of the news but also convert the news production process. The news production activities of internet journalism have entered a new stage with automatically generated news contents. Researchers dub the automation in news production in various names such as robot journalism, robo-journalism, software generated content, automatically generated content, algorithmic news, computerized news and automated news. The literature part of the present study focuses on the usage areas of the automated news production technologies. The new ethical problems related to this phenomenon, transformation in the newsrooms and modifications in the educational contents are discussed in the second section of the research with in-depth interviews conducted in Turkey in the context of actor network theory. The present situation of the automated news has been examined by the interviews with the software engineers, journalists, and academics from the disciplines of computer engineering and communication sciences. The interviews are fundamentally focused on the new journalistic job types and descriptions related to "cyborg journalism". Some particular recommendations for

Bu makaleye referans vermek için: Bilge N., (2017). Uzman Görüşleri Bağlamında Haber Üretiminde Otomatikleşme: Robot Gazetecilik. Galatasaray Üniversitesi Ileti-ş-im Dergisi, 27, 79-108. 
automated news reporting and verification processes are also considered in the context of journalism education.

keywords: robot journalism, cyborg journalism, actor network theory, news, news production, journalism

\section{Résumé}

\section{L'automatisation de la production des nouvelles dans le contexte des opinions des spécialistes : le journalisme robotisé}

Les évolutions des technologies liées à l'internet n'influencent pas uniquement la diffusion et la consommation de l'information, mais aussi le processus de production. Les contenus automatiques réalisés par les ordinateurs dans le cadre des activités de production du journalisme internet, ont débuté une nouvelle ère. Dans le cadre de cette recherche, nous avons étudié les champs d'utilisation des pratiques journalistiques connues sous plusieurs appelations telles que le journalisme-robot, contenu produit par un programme, contenu produit automatiquement, information algorithmique, information produite par l'ordinateur ou encore information automatisée. Dans la partie empirique de l'étude, nous avons analysé les changements et les transformations qu'a engendré le journalisme-robot dans les salles de rédaction, dans le secteur du journalisme, mais aussi dans le contenu de l'enseignement des facultés de communication. Ensuite, nous avons tenté de comprendre si cela a créé de nouveaux problèmes étiques. Pour répondre à cette question, nous nous sommes appuyés sur les entretiens réalisés en Turquie en nous basant sur la théorie de l'acteur réseau. Dans cette étude, nous avons sollicité les universitaires en génie informatique et en communication, mais aussi les programmeurs et les journalistes, afin de déterminer la situation actuelle. Par ailleurs, lors des entretiens, nous avons traité avec attention la question des nouvelles descriptions d'emplois issues des nouvaux genres de journalisme et du cyberjounalisme. Enfin, nous avons développé des propositions concernant l'information automatisée et les processus de vérification dans l'enseignement du journalisme.

mots-clés : journalisme-robot, cyberjounalisme, théorie de l'acteur réseau, information, production de l'information, journalisme. 
Öz

Internet teknolojilerindekigelișmeleryalnızca haberlerin dağıtımı ve tüketimi üzerinde değil, üretim süreci üzerinde de etkili olmaktadır. Internet gazeteciliğinin üretim faaliyetlerinde bilgisayar tarafından geliştirilen otomatik içeriklerle birlikte yeni bir evreye girilmiştir. Bu araştırmada robot gazetecilik, robo-gazetecilik, yazılım tarafından üretilen içerik, otomatik olarak üretilen içerik, algoritmik haber, bilgisayar tarafindan yazılan haber ve otomatize haber gibi çeşitli adlarla anılan bu gazetecilik pratiklerinin kullanım alanları incelenmiştir. Araştırmanın ikinci bölümünde ise robot gazeteciliğin haber odalarında, gazetecilik sektöründe ve iletişim fakültelerinin eğitim içeriğinde ne tür değişiklik ve dönüşümlere neden olduğu, mevcut etik sorunlara yenilerini ekleyip eklemediği gibi sorulara aktör ağ kuramı bağlamında Türkiye'de gerçekleştirilen derinlemesine görüşmelerle yanıt aranmıştır. Çalışmada bilgisayar mühendisliği ve iletişim bilimleri disiplinlerindeki akademisyenlerin yanı sıra, yazılımcılar ve gazeteciler ile görüşülerek mevcut durum saptanmıştır. Görüşmelerle ayrıca, yeni habercilik türleri ile "cyborg gazetecilik" temelli yeni iş tanımları üzerinde durularak, gazetecilik eğitiminde otomatize haber ve doğrulama süreçlerine yönelik öneriler de geliştirilmiştir.

anahtar kelimeler: robot gazetecilik, cyborg gazetecilik, aktör ağ kuramı, haber, haber üretimi, gazetecilik 


\section{Giriş}

Teknolojik gelişmelerin gazetecilik meslek pratiklerinde, içerikte ve içeriğin alımlanma aşamalarında yarattığı değişim akademik araştırmaların ilgi alanı olagelmektedir. Teknolojinin gazetecilik pratiklerine nüfuzu yeni bir çalışma alanı olmamakla birlikte, yazılımlarla oluşturulan otomatik haberler yeni ve tartışmalı bir alan olarak karşımıza çıkmaktadır. Günümüzde gazetecilik ve bilgisayar mühendisliğinin çalışma alanları giderek daha fazla yakınsarken, otomatik haber üreten yazılımlar gazetecinin rolü ve öz yetenekleri konusunda yeniden düşünmemizi gerekli kılmaktadır.

Robotların insanların yapabildiği tüm işleri kaçınılmaz bir biçimde üstlenerek insanlığı esir aldığını gösteren senaryolar, senelerdir tartışılmaktadır. Günümüzde ise bu senaryoların gazetecilik sektörü için belli oranda gerçekleştiği bir döneme gelindiği söylenebilecektir.

Önceleri robotların yalnızca "mavi yakalı" olarak tanımlanan ve çoğunlukla beden gücüne dayalı işleri üstleneceği düşünülmekteydi. Beyaz yakalı işlerin ise koruma altında olduğuna dair yaygın bir kanı bulunmaktaydı. Oysa, sofistike algoritmaların gelişmesi ile artık iş güvencesinin kalmadığı gözlenmektedir. Başka bir anlatımla, gazeteciler uzmanlaşmış oldukları için kendilerini toplumdan farklı bir profesyonel grup olarak algılama eğiliminde olsa da (Jung vd. 2017, s. 292), özellikle sofistike algoritmaların artması ile beceri ve uzmanlık gerektiren çok sayıda iş kolu gibi gazetecilik de otomatikleşme sürecine girmiş durumdadır.

Haber içeriğini toplamak, dağıtmak ve yayınlamak için bilgisayarların ve yazııımın kullanımı her geçen gün artmaktadır (Clearwall, 2014). Algoritmalar artık bir dizi basmakalıp söz ve istatistiksel enformasyon ile insan müdahalesine gerek kalmaksızın haber yazabilmektedir. Haber üretiminin her bir aşaması otomatik hale gelmekte, düşük bir maliyetle binlerce haber saniyeler içerisinde oluşturabilmektedir (van Dalen, 2012, s. 648-649).

En genel adıyla "robot gazetecilik" (Clerwall, 2014; Dawson, 2010; Van Dalen, 2012) olarak adlandırılan bu otomatizasyon süreci, bilgisayarlı gazeteciliğin (computational journalism) yeni bir evresi olarak kabul edilmektedir. Bu gazetecilik türü "otomatize içerik", "algoritmik haberler" (Graefe, 2016; Bunz, 2010; Levy, 2012), web 3.0 gazetecilik, robo-gazetecilik, otomatize haber yazılımı, yazılım tarafından oluşturulan içerik ve otomatik olarak üretilen içerik (Clerwall, 2014, s. 519) gibi başkaca adlarla da anılmaktadır. Kavram en basit şekliyle, başlangıçtaki programlama aşaması dışında insan müdahalesi olmaksızın veriyi haber metnine dönüştüren algoritmik süreç olarak tanımlanabilecektir (Carlson, 2014, s. 416). Başka bir anlatımla robot gazetecilik, algoritmaların belli konulardaki haber klişelerini depolayıp anlamlandırması sonucunda güncel verilerden benzer otomatik haber metinleri oluşturulmasıdır. 
Gazetecilik pratiklerindeki bu otomatikleşme süreci, dil dışı girdilerle otomatik olarak doğal dil üretme (NLG /Natural Language Generation) çalışmalarının bir uzantısı olarak kabul edilmektedir. Bu alandaki ilk çalışmalar, sabit ya da çok az değişiklik gösteren basit ve standart metinlerin üretiminden ibarettir. Ancak yıllar geçtikçe, daha fazla dilsel anlayış içeren ve çeşitlilik gösteren metinler üretmek amacıyla da teknikler geliştirilmiştir (Van Deemter vd., 2005). Günümüzde Narrative Science, Automated Insights, Yseop ve CBS Interactive gibi şirketlerin yanı sıra Fantasy Journalist gibi yeni başlayan şirketler, ilk NLG teknolojilerinden çok daha sofistike ve "insan yazımına benzeyen" otomatik metinler oluşturmaktadır (Van der Kaa ve Krahmer, 2014, s. 2).

Robot gazeteciliğin yaygınlaşmasında doğal dil işleme teknolojilerindeki gelişmelerin yanı sıra büyük veri analitiği de etkili olmuştur. İletişim teknolojileri artık daha önce mümkün olmayan hacimdeki verinin hızlı, kolay bir şekilde toplanmasına, depolanmasına ve analiz edilmesine olanak tanımaktadır (Lewis ve Westlund, 2014). Dahası, verilerin kendiliğinden konuşmasına izin verilmekte, raporlamadaki insan boyutu giderek azalmakta, "otomatikleştirilmiş" veya "robotik" raporlama giderek yaygınlık kazanmaktadır (Carlson, 2014). Bir başka anlatımla, robot gazetecilik kavramı büyük veri gazeteciliği ile yakın ilişki içerisindedir. Çünkü veri, her şeyden önce robot gazeteciliğinin maddi sebebidir.

Vergi kayıtları, okul sınavı sonuçları, mali raporlar, üyelik listeleri, seçim sonuçları ve hisse senedi fiyatları otomatize içerik oluşturulurken sıklıkla kullanılan yapılandırılmış nicel veri örnekleridir. Ayrıca çok çeşitli belgeler, resimler ve görsel-işitsel malzemeler gibi yapılandııımamış veriler de içerik oluşturmada kullanılabilmektedir (Karlsen ve Stavelin, 2014, s. 36).

Bu çalışmanın amacı hem araştırmacılar hem de uygulayııılar için yeni bir alan ve haber odalarının yeni eğilimi olan robot gazeteciliğin meslek pratiklerinde yarattığı dönüşümü konunun uzmanlarının görüşleri bağlamında tartışmaya açmaktır. Bu kapsamda, araştırmanın ilk bölümünde otomatize haber içeriğinin kullanım alanları neden olduğu sorunlar ve yarattığı fırsatlar ekseninde ele alınmaktadır. Araştırmanın ikinci bölümü ise, sosyo-teknolojik temelli aktör ağ kuramı ekseninde gerçekleştirilen derinlemesine görüşme verilerine dayanmaktadır. Çalışmada bilgisayar mühendisliği ve iletişim bilimleri disiplinindeki akademisyenlerin yanı sıra yazılımcılar ve gazeteciler ile görüşülerek robot gazeteciliğe ilişkin sorular yöneltilmiştir.

Aktör ağ kuramına göre bilim ve teknoloji temelde diğer toplumsal faaliyetlerden bağımsız değildir. Aksine varlık ve olguların etkileşiminden doğan sonuçlarla incelenmelidir. Aktör ağ kuramı, insanları birer aktör olarak nitelerken, insan dışı varlıkları "eyleyenler" anlamında "actant" olarak tanımlamaktadır (Alexander ve Silvis, 2014). Turner (2005), yeni medya teknolojilerinin haberci, metin ve izleyici arasındaki keskin sınırları aşındırdığına dikkat çekerek, aktör ağ 
kuramının gazetecilik pratiklerindeki dönüşümü anlamada da kapsamlı, önemli ve bütüncül bir araç olabileceğini belirtmektedir.

Geleneksel gazetecilik çalışmalarında aktörler genellikle üç başlık altında incelenmektedir: Kaynaklar, gazeteciler ve okurlar/izleyiciler/kullanıcılar. Bu aktörlerin hepsi insandır ve aralarında belirli bir ayrım vardır. Yeni iletişim teknolojilerindeki gelişmeler bu kesin analitik kategorilere dayanan geleneksel okumaların yetersizliğini ortaya koymaktadır. Geleneksel yaklaşımlar, gazetecilik pratikleri ve dijital teknolojileri değerlendirirken kitle iletişim araçlarını enformasyonun dağıtımına yarayan araçlar olarak görmektedir. Aktör ağ kuramı ise, hem teknolojik araçların hem de onları kullanan insanların bir ağ olarak kabul edebileceğimiz haber odasındaki iş birliğinin ve etkileşiminin yeni sosyo-teknolojik oluşumların ortak yaratıcısı olduğuna işaret etmektedir (Turner, 2005, s. 322-323; Kumar ve Haneef, 2016, s. 105).

Bu çalışmada, otomatik haber yazılımları ile birlikte internette haber üretiminin nasıl değiştiğini saptamak için bir çerçeve olarak aktör ağ kuramı kullanmaktadır. Bu kapsamda, yeni bir aktör olarak karşımıza çıkan otomatik haber yazılımlarının haber üretim sürecine nüfuzu konunun uzmanlarının görüşleri ekseninde tartışılmaktadır.

\section{Robot Gazeteciliğin Kullanım Alanları}

Otomatize işlemler gazetecilerin haber toplamasından örgütsel yapısına, verilerin analizinden haber üretimine pek çok aşamada zaten kullanılmaktaydı. Ancak gazeteciler gerçek haberciler olarak otoritelerini korumaktaydı. Robot gazeteciliğin gelişmesi ile birlikte ise, iş bölümünde sarsıcı bir değişiklik öngörülmektedir. Bu nedenle kavram, gazetecilik mesleğinin geleceği konusundaki tartışmaların temel konusu olmaktadır. Bu kapsamda, öncelikle otomatik haber üreten algoritmaların tarihsel gelişimini ve yaygın kullanım alanlarını serimlemek kayda değer gözükmektedir.

Aslında algoritmalar yalnızca haber yazmada değil haber seçmede ve düzenlemede de uzunca bir süredir kullanılmaktadır (Jung vd. 2017, s. 291). Örneğin İngiliz The Guardian gazetesi otomatik olarak en çok okunan haberleri bir araya getirerek, onlardan haftalık basılan bir gazete çıkarmaktadır (Ellis, 2013). Arama motoru Google'ın da haberleri gösterirken algoritmalardan yararlandığı bilinmektedir.

Günümüze gelindiğinde ise, özellikle büyük medya şirketleri tarafından finanse edilen ana akım medyada yer alan ve yapılandırılmış verilerden oluşan rutin haber metinlerinin çoğu otomatik olarak oluşturulmaktadır. Bir başka anlatımla robot gazetecilik olay temelli (fact-based), temiz, yapılandırılmış ve güvenilir verinin olması durumunda gerçekleşebilmektedir (Graefe, 2016). Mevcut kullanım alanları ise hava durumu, spor, suç istatistikleri, şirketlerin kâr zarar 
tabloları, mali raporlar ve gayrimenkul gibi detaylı sayısal veri içeren haberlerdir. Ancak gelecekte, tüm haber türlerinde otomatik algoritmaların kullanılabileceği öngörülmektedir. Öyle ki, Narrative Science'tan Kristian Hammod 2030 yılında haberlerin \%90'ının makineler tarafından yazılacağını iddia etmektedir. Pulitzer ödülünün sembolik olarak bir robot yazılıma verilmesi de olasılıklar arasındadır (Adams, 2015).

Robot gazeteciliğin dünyadaki gelişim seyrine bakıldığında, 2006 yııında Thomson Reuters ín finans haberlerini derlemek için algoritmaları kullanacağını açıklaması önemli bir milat olarak kabul edilmektedir (Momus, 2006). Kasım 2010'da ise dijital medya şirketi Statsheet, kolej basketbol takımlarının 15 binden fazla maçına ilişkin oyun ön izlenimlerini de içeren haber metinlerini her ay, insan müdahalesine gerek kalmaksızın haberleştirmiştir (Statsheed, 2011). Böylece algoritmalar, oyun istatistikleri ve bir dizi basmakalıp söz aracılığıyla otomatik olarak haber yazabilecek yetkinliğe ulaşmıştır (van Dalen, 2012, s. 648).

Mary Lynn Young ve Alfred Hermida, Los Angeles Times'ın cinayet raporunu otomatik gazeteciliğin erken dönem örneklerinden kabul etmektedir. Projenin Ocak 2007'de piyasaya sürülmesinden önce gazetenin basılı hali, Los Angeles'ta kaydedilen yıllık yaklaşık bin cinayetin yalnızca en sansasyonel olan yüzde onunu haberleştirmekteydi. Cinayet Raporunun amacı, tüm cinayetlerin ayrıntııı bir şekilde kapsanması yoluyla haber seçimindeki bu önyargıya değinmekti (Graefe, 2016).

Alandaki bu ilk gelişmelere karşın, bazı kaynaklar Los Angeles Times'ın 2014 yıında deprem ile ilgili bir haberi otomatik yazılım sayesinde hızla yayınlamasını gerçek anlamda robot gazeteciliğin ilk örneği olarak kabul etmektedir. Ken Schwencke tarafından yazılan algoritma sayesinde haber, depremin meydana gelmesinden yalnızca üç dakika sonra yayına girmiştir (Oremus, 2014).

Yine alandaki örneklere paralel olacak şekilde, Automated Insight ve Narrative Science otomatize haber içeriği sağlayan öncü kuruluşlar olarak kabul edilmektedir. Örneğin Nortwestern Üniversitesi'nin akademik bir projesi olan StatsMonkey, Narrative Science'ın ilk prototipi olarak beyzbol maçlarını özetlemiştir (Levy, 2012). Bu gelişmeden kısa bir süre sonra Forbes, ilgili kuruluş ile otomatik haber içeriği üretimi konusunda anlaşma sağlamıştır. Associated Press ise Automated Insights ile ortaklık kurduğunu açıklayarak üç aylık finansal raporlarını otomatik olarak oluşturacaklarını duyurmuştur (Tornoe, 2014, s. 24). Böylece otomatik haber içerikleri, özellikle ana akım medya kuruluşlarında, belirsizliğe ve yoruma kapalı metinlerin oluşturulmasıyla hızla haber odalarına eklemlenmeye başlamıştır.

Amerikan medyasının dışında dünyanın diğer ülkelerindeki şirketler de otomatik yazııımlar tarafından oluşturulmuş içerik akımına uymuş durumdadır. Almanya'da AX Semantics, Text-on, 2txt NLG, Retresco, Textomatic'in yanı sıra 
Fransa'da Syllabs ve Labsense, Ingiltere'de Arria, Çin'de Tencent ve Kore'de The Financial News öne çıkan şirketlerdir (Graefe, 2016; He, 2015; Son, 2016). Dikkat edilmesi gereken konulardan biri, bu şirketlerin kendilerini gazetecilik faaliyeti gösteren kurumlar olarak tanımlamamalarıdır. Bu işletmeler veri ile ilgili endüstriler olup, ürün tanımlama, portfolyo analizi ya da hastaneler için hasta özetleri oluşturma gibi başkaca işler de yapmaktadır (Graefe, 2016). Rus arama motoru Yandex'in de, haberleri duyururken robot muhabirlerden yararlandığı bilinmektedir.

Robot gazetecilik alanındaki gelişmelerin, büyük veri tartışmaları ile doğrudan bir bağı bulunmaktadır (Van Der Haak vd., 2012; Lewis, 2015). Verideki artış, insan emeği ile analiz etmenin çok zaman alacağı haber konularının gündeme gelmesine neden olmaktadır. Bu durumun en güncel örneklerinden biri, 1977'den beri biriktirilen ve iki yüzü aşkın ülkedeki ünlülerin, iş adamlarının ve siyasetçilerin sırlarını içeren 11.5 milyon dokümandan oluşan Panama Belgeleri'dir. Süddeutcsche Zeitung adlı Alman yayın kuruluşu, belgelerle tek başına baş edemeyince, merkezi Washington D.C.'de bulunan The International Consortium of Invastigative Journalim adlı merkeze yardım talebi ile başvurmuştur. Böylece belgelerin aranabilir hale getirilmesi için, iş birliğine gidilmiştir. Bu olay geleneksel gazetecilik iş pratiklerini yerinden eden örneklerden biri olarak kabul edilmektedir. Çünkü belgeler saklanmamış paylaşılış, rekabetçi medya ortamının doğasına ters biçimde iş birliğine gidilmiştir. Gazeteciliğin tarihinin en büyük iş birliği olarak kabul edilebilecek olayda, çeşitli ülkelerden davet edilen gazetecilere iki hatırlatmada bulunulmuştur: Belgelerde buldukları haberleri herkesle paylaşmaları ve tüm gazetelerin aynı gün yayına çıkması. Önemli bir arama motoru teknolojisi kullanmayı gerektiren olay sonunda, belgelere ilişkin ilk haberler 3 Aralık 2016 tarihinde 76 ülkede Almanya saati ile 19.00'da yayımlanmıştır. Bu durum, gazetecilerin hacmi büyük veride önemli olan bilgiyi arama yollarına dair beceriye sahip olmaları gerektiğini ortaya koymasının yanı sıra, miktarca fazla belgede anormal ya da sıra dışı olarak adlandırılabilecek olayları tespit etmede otomatik yazıııların gerekliliğini de gündeme getirmiştir.

Algoritmaların gazetecilik mesleğinde kullanıldığı bir başka alan ise otomatize doğrulama süreçleridir. "Fact-checking" olarak adlandırılan ve mevcut haberlerin doğruluk ya da yanlışlığının tespiti için emek harcayan kuruluşlar da post-truth tartışmalarına paralel olacak şekilde güncel bir gelişme olarak karşımıza çıkmaktadır. Otomasyon haber odalarında yaygınlaştıkça, enformasyon doğrulamada otomatik yollar da (Hassan vd., 2015 ve Ciampaglia vd., 2015) kaçınılmaz olarak gündeme gelmektedir. Gerçek zamanlı haber doğrulama algoritmaları henüz yaygınlık kazanmamış olsa da çeşitli denemeler bulunmaktadır.

Görüldüğü üzere rutin ve sayısal veri içeren haber metinlerinin otomatikleşmesiyle başlayan süreç, giderek diğer habercilik faaliyetlerine de yayılmaktadır. Algoritmik hesap verebilirlik ve büyük veri analizinin, geleceğin gazeteciliğinin önemli teknolojik gelişmeleri olmayı sürdüreceği söylenebilecektir. 
Bu nedenle, otomatik haber içeriklerinin gazetecilik meslek pratiklerinde yarattığı fırsatlar ile neden olduğu tehditler ekseninde karşılaştırmalı olarak analiz edilmesi, bütünsel bir kavrayış sağlamak açısından önemlidir.

\section{Fırsatlar ve Tehditler Ekseninde Robot Gazetecilik}

Otomatik haber içerikleri haber üretimi, içerik ve okurlar açısından değerlendirildiğinde, bir yandan eski sorun alanlarına eklemlenen yeni sorunlara neden olurken, öte yandan bazı fırsatlar da yaratmaktadır. Bazı araştırmacılar robot gazeteciliğin insan gazetecilere olan ihtiyacı ortadan kaldırarak gazetecilik mesleğinin sonunu getireceğine dair karamsar senaryolar yazmakta, diğerleri ise gazetecileri rutin iş yükünden kurtararak daha derinlikli ve nitelikli haberler için onlara zaman kazandıracağına dair iyimser öngörülerde bulunmaktadır.

Tablo 1: Insan gazeteciler, robot gazetecilik olgusunu nasıl yorumluyor? (Kaynak: van Dalen, 2012, s. 655) (Statsheet Network'un otomatik spor içeriklerini tartışan 68 blog yazısı ve haber makalesinden derlenmiştir).

\begin{tabular}{|l|l|}
\hline Güçlü Yanlar & Zayıf Yanlar \\
\hline $\begin{array}{l}\text { Yaratıcılık, insan gazetecilerin klişelerin ötesine } \\
\text { geçmelerine ve haber metinlerine mizah } \\
\text { unsuru eklemelerine olanak sağlar. }\end{array}$ & $\begin{array}{l}\text { Insan gazeteciler otomatik içerik üretimine } \\
\text { göre daha fazla marjinal maliyete sahiptir. }\end{array}$ \\
\hline $\begin{array}{l}\text { Esneklik, insan gazetecilerin anlık son dakika } \\
\text { haberleri gibi rutin içeriklerin dışında haberleri } \\
\text { oluşturmasına olanak sağlar. }\end{array}$ & $\begin{array}{l}\text { Insan gazeteciler otomatik içerik ile aynı } \\
\text { uzunlukta haberi yazamaz }\end{array}$ \\
\hline $\begin{array}{l}\text { Analitik yetenekler, insan gazetecilerin } \\
\text { tanımın ötesine geçerek derinlemesine bilgi } \\
\text { sağlamalarına fırsat verir. }\end{array}$ & $\begin{array}{l}\text { Insan gazeteciler otomatik içerik üretiminin hızı } \\
\text { ile yarışamaz. }\end{array}$ \\
\hline Fırsatlar & Tehditler \\
\hline $\begin{array}{l}\text { Otomatik rutin metinler, insan gazetecilere } \\
\text { daha derin haberler için araştırma yapmaları } \\
\text { için zaman sağlar. }\end{array}$ & $\begin{array}{l}\text { Otomatik içerik oluşturma gazetecilerin rutin } \\
\text { işlerini devralarak işsiz kalmalarına neden } \\
\text { olabilir. }\end{array}$ \\
\hline $\begin{array}{l}\text { Otomatik içerik üretimiyle rekabet, insan } \\
\text { gazetecileri daha iyi iş yapmaya zorlar. }\end{array}$ & $\begin{array}{l}\text { Otomatik içerik oluşturma spor muhabirliğinin } \\
\text { ötesinde, finans veya gayrimenkul } \\
\text { gazetecilerinin de işlerini kaybetmelerine } \\
\text { neden olabilir. }\end{array}$ \\
\hline $\begin{array}{l}\text { Otomatik içerik üretimi, küçük izleyici } \\
\text { grupları için şu an ele alınmayan haberlerin } \\
\text { öyküleştirilmesine neden olabilir. }\end{array}$ & $\begin{array}{l}\text { Otomatik içerik üretimi şeffaflık ve fikri haklar } \\
\text { gibi yeni etik sorunları arttırabilir. }\end{array}$ \\
\hline
\end{tabular}

Tablo 1'de insan gazeteciler ve robot gazeteciliğe dair karşılaştırmalı bir analiz yer almaktadır. Robot gazeteciliğin en önemli iki olumlu etkisi insan kaynağına bağlı maliyeti düşürme ve zamandan tasarruf olarak betimlenmektedir. Gazeteciliğin otomasyonu, yüksek kâr marjı ve daha düşük üretim maliyeti hedefleyen piyasa eğilimleriyle uyuşmaktadır (van Dallen, 2012, s. 651). İşgücü maliyetlerini azaltmak için yeni yol ve yöntemler aranması gazetecilik için yeni 
bir durum değildir. Ancak haber üretiminde otomasyon ve algoritmaların artan kullanımı ile pazar odaklı perspektifler yeni bir boyut kazanmaktadır (Thurman vd., 2017, s. 3). Görüldüğü üzere "olumlu" olarak atfedilen özellikler genellikle gazetecinin çalışma koşullarında bir iyileşme değil, aksine sektörün kapitalist çalışma pratiklerinde daha fazla kâr elde etmesiyle temellendirilmektedir. Gazeteciler açısından olumlu olarak nitelendirilenler ise, muhabirlerin günlük rutin ve basit iş tanımlarından kurtularak, detaylı araştırma ve derin yazma için daha fazla zaman kazanacak olma olasııılarıdır.

Benzer şekilde haber endüstrilerinin haber üretim süreçlerini yenileyerek haberleri daha hızlı, daha geniş ölçekte ve daha az hata ile okurlarına sunabilecekleri öngörülmektedir (Jung vd. 2017, s. 292). Yine algoritmalar, aynı haber metnini farklı dillerde ve farklı açılardan kurgulayarak, kullanıcıların kişisel tercihleriyle belirlenen seçenekler sunabilmektedir. (Graefe, 2016). Örneğin Automated Insigts'tan Adam Smith, algoritmaların 10 milyon kişi tarafından okunacak bir metin yazmak yerine, bir ya da iki insanın okuyacağı 10 milyon metin yaratma potansiyelinden söz etmiştir (Tornoe, 2014).

Özetleyecek olursak, iyimser yaklaşımlar gazetecilik mesleğinin öleceğine ilişkin abartıı iddialara mesafeli durmaktadır. Bu bakış açısına göre, tarihin her döneminde yeni bir teknoloji ortaya çıktığında felaket senaryoları üretilmiştir.

Olumsuz yaklaşımlar ise tarihin diğer dönemlerinden farklı olarak, artık görece nitelikli orta sınıfın da tehlike altında olduğuna işaret etmektedir. White bu durumu şöyle açıklar:

\begin{abstract}
1589 'da yün örgü makinaları el örgücülerin yerini aldığında da Kraliçe Elizabeth tüm örgücülerin dilenci olacağı endişesi taşıyarak bu buluşu yasaklamıştır. Ancak geçmişte, yetenekli çalışanlar makineleri kullanmak üzere yalnızca yetenekli olmayanların yerini almaktaydı. Bugün ise az sayıda çok iyi eğitimli ve hiper-yetenekli çalışan (geekler ve bilgi teknolojisinde uzmanlaşmış, hevesli kişiler olarak tabir edilen techi'ler) yetenekli orta sınıf çalışanlarını da yerlerinden etmektedir (2016, s. 15).
\end{abstract}

Olumsuz yaklaşımlara göre, algoritmaların daha nesnel haber sunacağına yönelik yaygın görüş de sorunludur. Çünkü algoritmalar hatalar içerebilen beklenmedik sonuçlar verebilmektedir. Matthews (2014) insan takliti yapan yapay zeka olarak tanımlanan botlar aracılığıyla yazılan otomatik haberlerin duygusal bağ kuramadığını, yaratıcı olmadığını, anlamlandırma yapamadığını, saldırgan bir dil kullanabildiğini, hacklenme ihtimali olduğunu, güvenilir olmayan kaynaklara başvurabildiğini ve haber-reklam dengesini kurmada başarısız olabildiğini belirterek, denetlenmeleri gerektiğini ifade etmektedir.

Yine algoritmalar mevcut halleri ile nedensellik kurmada, soru sormada ve yeni bir fenomeni açıklamada yetersizdir. Bilgisayar tarafından oluşturulan içerik sıkıcı ve klişelerle dolu olarak nitelenmektedir (van Dallen, 2012, s. 653). Kullanıcı 
memnuniyeti açısından değerlendirildiğinde, otomatik haber içerikleri daha güvenilir bulunmakla birlikte, eğlenceli bir içerik sunamamaktadır. Hızlı bir olay haberciliğinin yaygınlaşması nitelikli habere ilişkin kullanıcı beklentisini zamanla azaltabilecektir (Graefe, 2016).

Otomatize haber içeriği ve kişiselleştirme seçeneklerinin artması ayrıca kamuoyunun kutuplaşmasına yönelik endişeleri yeniden gündeme getirebilecektir (Graefe, 2016). Haber sayısındaki artışa atfedilen olumlu nitelemeler bu nedenle abartılıdır. Çünkü bu durumda okurlar, değerli bilgivi bulmakta zorlanacak ve enformasyon miktarındaki hızlı artış, enformatik cehaleti de beraberinde getirecektir.

\section{Önceki Araştırmaların Bulguları}

Robot gazeteciliğin haber odalarında kullanımının yaygınlaşmasıyla birlikte alana olan akademik ilginin de arttığı görülmektedir. Araştırmalar dayandıkları kuramlara, yöntemlerine, konularına ve araştırma birimlerine göre değişiklik göstermektedir. Bu kapsamda ilgili literatürün incelenmesi, alana özgü akademik çalışmaların haritasını çıkarabilmek için önemlidir.

Alandaki ilk çalışmaların otomatik içeriğin niteliği üzerinde durduğu gözlenmektedir (Bangalore, Rambow ve Whittaker, 2000; Belz ve Gatt, 2008). Metinlerin dil bilgisi açısından doğru ve tutarlı olup olmadığı, gerekli bilgileri uygun biçimde derleyip derleyemedikleri bu tür araştırmaların temel meselesi olmuştur.

Günümüzde ise, otomatize haberlerin güvenilirliği yaygınlık kazanmaya başlayan bir çalışma alanı olarak karşımıza çıkmaktadır. Bu kapsamda Clerwall (2014) yaptığı küçük ölçekli bir deneysel çalışmada, bilgisayar dolayımıyla oluşturulan haberlerin gazeteciler tarafından yazılan haberlere kıyasla okurlar tarafından nasıl alımlandığını sorgulamıştır. Araştırma sonucunda, okurların robot gazetecilerce oluşturulan otomatik metinleri insan gazeteciler tarafından oluşturulan haberlere göre daha betimsel ve sıkıcı olarak niteledikleri ancak daha nesnel bulunduklarını saptamıştır. Bu ilk küçük çaplı çalışmayı genişleten Van der Kaa ve Krahmer (2014) ise, spor ve finansla ilgili haberler üzerinden benzer bir deney yapmışlardır. 64'ü gazeteci olmak üzere 232 kişi ile Hollanda'da yapılan çalışmanın sonunda, haber tüketicilerinin haberin doğruluğu konusunda pozitif ya da negatif bir ayrımda bulunmadığı saptanmıştır. Önceki araştırmadan farklı olarak, bu araştırmada katılımcılar bilgisayar tarafından oluşturulmuş bir haber okuduklarından haberdardır. Araştırmanın bir diğer önemli bulgusu ise gazetecilerin kendilerini otomatik haber üreten meslektaşlarına göre daha güvenilir olarak nitelemeleri olmuştur. Diğer okurlar ise böyle bir geri bildirimde bulunmamıştır.

Okurları temel alan üçüncü araştırma Güney Kore'de 400 kişi üzerinde çevrimiçi anket yoluyla gerçekleştirilmiştir (Jung vd., 2017). Araştırma sonunda 
haberi kimin yazdığının manipüle edilmesi durumunda okur değerlendirmelerinin değişiklik gösterdiği ortaya konulmuştur. Örneklem olarak seçilen haberlerin iyi yazıımış, açık, güvenilir ve profesyonel olup olmadığının sorgulandığı çalışmada, haberi yazan algoritma olarak bildirildiğinde kamuoyunun haberlere daha yüksek puanlar verdiği saptanmıştır. Ancak yazarın yanıltıcı biçimde gazeteci olarak belirtildiği durumlarda, okurlar algoritmaların yazdığı haberlere daha düşük oy vermiştir. Bu durumun kamuoyunun Güney Kore'de gazetecilere güven konusundaki olumsuz tavrını doğruladığı sonucuna varıımıştır.

Bir diğer araştırma tasarımı ise, haber odalarında robot gazeteciliğin yarattığı dönüşümü saptamaya yöneliktir. Bu kapsamda, Royal (2012) New York Times'ın Interaktif Haber Teknolojisi Bölümü'nde gerçekleştirdiği çalışmanın sonunda, yeni medya atmosferinde ihtiyaç duyulan önemli becerilerin genel sorun çözme, web teknolojilerini kullanma ve onlara hâkim olma olduğunu saptamıştır. Korsan kültürünün yaratıcılık, yenilik ve iş birliği özellikleri de artık haber odalarında yaygınlık kazanmaktadır.

Norveç'teki en büyük altı haber merkezindeki uzman uygulayıcılarla yapılan derinlemesine görüşme verilerin incelendiği bir başka çalışmada, bilgisayarlı gazeteciliğin geleneksel araştırmacı gazeteciliğin devamı olarak betimlendiğinin altı çizilmiştir. Haber odalarında geleneksel gazetecilik süreci ve değerlerinin takip edildiği, ancak hem önceden hazırlanmış hem de projeye özgü programların kullanımıyla bazı durumlarda yazılım desteğinin alındığı saptanmıştır (Karlsen ve Stavelin, 2014).

Thurman vd. (2017), İngiltere'deki gazetecilerin robot gazetecilik hakkındaki fikirlerini incelemişlerdir. Araştırmada bu teknolojiyi kullanan CNN, BBC, Thomonson Reuters, Trinity Mirror ve The Sun gibi bu teknolojinin önde gelen kurumlarda çalışan, robot yazılımlarla çalışma deneyimine sahip 10 gazeteci ile görüşülmüştür. Araştırma sonucunda otomatik haber içeriklerine ilişkin bazı sınırlılıklar tespit edilmiştir: Robot gazetecilik tek ve izole edilmiş veri akışlarına güvenmektedir. Kaynak olarak alınan veriyi doğrulamada zorluklar yaşanmaktadır. Üretilen metinlerde insani bir boyut bulunmamaktadır. Haberlerin önceden şablonlaştırılması gerekmektedir (s. 15).

Son dönemde ise robot gazeteciliğin kapasitesi, nitelikleri, okur tarafından alımlanması ve haber odalarında yarattığı dönüşümden ziyade, bu yeni üretim aracının neden olduğu ya da olabileceği etik sorunlar tartışımaya başlanmıştır. Her şeyden önce robot gazetecilikte normatif standartları kontrol etmek gittikçe zorlaşmaktadır (Creech ve Mendelson, 2015, s. 149). Thurman vd. algoritmaların neden olduğu yeni etik sorunlara ilişkin literatürü inceleyerek şu başılıları öne çıkarmışlardır: Gazetecilerin dijital veriyi nasıl elde ettiği, doğruladığı ve kullandığı, algoritmalarda yanlılık olasılığı, kod ve verilerin şeffaflığı sorunu (2017, s. 4). 
Bazı kuruluşlar, algortimaların yanılabileceğinden hareketle, okurlara bir haberin otomatik olarak üretildiğini söylemenin etik bir zorunluluk olduğunu düşünmektedir. Örneğin $A P$ otomatik haber içeriklerinin altına, metnin otomatik oluşturulduğuna dair bir uyarı notu düşmektedir.

Robot gazetecilik etiğini konu edinen çalışmalardaki temel tartışma konusu veriye ilişkin fikri haklar olarak karşımıza çıkmaktadır. Algoritmalar yalnızca resmi kaynaklara mı bağımlı olacaktır? Yoksa bir kolej spor karşılaşması, oyunculardan birinin babasının sanal ortama yüklediği yorumları güvenilir bir bilgi olarak kabul edecek midir? (Kent, 2015). Görüldüğü üzere otomatize içeriğin dayandığı verilerin kaynağı da önemli bir tartışma konusudur.

Algoritmaların yalnızca belirli kaynakları seçerek manipülasyon yapabileceği bilinmektedir. Robot gazetecilik etiğini konu alan araştırmalarda, bu manipülasyonun en aza indirilmesi için haber üretim sürecinin şeffaflığının algoritmalar için de geçerli olması gerektiği sıkıkla dile getirilmektedir. Örneğin bir araştırmada, 28'i medya endüstrisinden 22'si ise akademiden 50 kişiyle yapılan bir odak grup çalışmasının sonunda medya kuruluşlarının algoritmik şeffaflığı teşvik etmediklerini saptanmıştır (Diakopoulos ve Koliska, 2016).

Özetleyecek olursak, teknolojinin yetkinliği, okur memnuniyeti, haber odalarındaki değişim ve etik sorunlar robot gazetecilikle ilgili sınırlı sayıdaki araştırmanın ilgi alanını oluşturmaktadır. Bu araştırmanın devam eden bölümlerinde, önce kuramsal bağlama yönelik açıklamalarda bulunulmuş, ardından mevcut durumun saptanması ve ilgili literatüre karşılaştırmalı veriler sunulabilmesi amacıyla Türkiye özelinde konu ile ilgili profesyonellerin görüşleri analiz edilerek tartışmaya açılmıştır.

\section{Aktör Ağ Kuramı ve Gazetecilik}

Aktör Ağ Kuramı (AAK), Emile Durkheim ve Auguste Comte'un klasik sosyolojisinde öngörülen doğa/toplum, mikro/makro, özne/nesne, iyi/kötü, insan/ hayvan, kadın/erkek ve bu araştırmanın da konusunu oluşturan insan/makine ikiliklerini öne süren pozitivist önermeyi reddeden bir yaklaşımdır. Bunun yerine, bu ikililerin kabul edilmediği ve tüm aktörlere eşit seviyede oyun alanı verilen düz bir ontolojiyi benimsemektedir (Dudhwala, 2009). Bu yaklaşıma göre hem insan aktörler hem de insan olmayan eyleyenler hareketli bir ağ üzerinde eşit güce sahiptir ve güçlerini bir diğeriyle birleştirmeleri yoluyla kullanırlar (Kumar ve Haneef, 2016, s. 108).

AAK, devam eden eylem üzerinde etkiye sahip her şeyi aktör olarak niteleyerek (Latour, 2005), aktörün tanımını ağda diğer unsurlarla etkileşimi sayesinde güç kazanan herhangi bir unsur (örn. insanlar, semboller veya makineler) (Hemmingway, 2007, s. 24) olarak genişletir. Böylece insan ya da insan dışı olup, üretim aşamasına ortak olan, üretim sürecini dönüştüren hiçbir 
şey yalnızca birer bağlam ya da ardyöre olarak kabul edilmez (Primo ve Zago, 2015 , s. 42). Bu yaklaşımda insanlar, idealler, sembolik yapılar, teknolojiler ve materyal unsurlar analiz için eşit derecede önemli öğeler olarak görülmektedir.

AAK teknolojik ve toplumsal belirlenim görüşlerinden kaçınmak için çok sayıda sosyoteknolojik yaklaşımın ötesine geçmeyi denemektedir. Bu yaklaşımda toplumsal ve teknik birbirinden ayrılmayacak şekilde karışmıştır. Hem teknolojik hem de toplumsal öğeler birlikte ve birbirleriyle etkileşimleri boyunca dönüştürücü güce sahiptir. (Ballantyne, 2015, s. 107-110). Bir başka anlatımla, AAK yeni bir teknolojinin yeni bir aktör olarak iş yapış pratiklerini diğer aktörlerle ilişkisi bağlamında nasıl değiştirdiğini serimleme amacıyla kullanılan bir kuramdır.

Son dönemde aktör ağ kuramının işlevselci perspektifi ile onun "toplumsal", "teknik" ve "kültürel" gibi önemli kavramlara olan şüpheci yaklaşımını gazetecilik pratiklerine uyarlayan çalışmalar yaygınlık kazanmaktadır (Kumar ve Haneef, 2016; Primo ve Zago, 2015; Fioravanti ve Velho, 2010, Plesner, 2009, Hemmingway, 2005). Bu çalışmalara göre gazeteciler haber odasında faaliyet gösteren insan aktörler olarak; altyapı ve teknolojiler ise insan dışı eyleyenler olarak karşımıza çıkmaktadır. Örneğin bir haber odasında merkezi bir sunucunun varlığı da tıpkı insan aktörler gibi haber üretim sürecinde önemli bir role sahip olabilmektedir (Hemmingway, 2005).

"Birlikteliklerin sosyolojisi" olarak anılan AAK, toplumsalı bir anlamlandırma ya da açıklama olarak değil bir araya gelen çeşitli aktörlerin sonucu olarak görür (Plesner, 2009, s. 612). AAK dijital gazetecilik üzerine yazılmış çalışmalarda teknolojik determinizm konusunun sıklıkla eleştirildiğini (Steensen, 2011) belirtirken, sosyal determinizmin gazetecilik teorilerine etkisinin ise göz ardı edildiğine işaret etmektedir. AAK temelli gazetecilik çalışmaları, ideoloji bağlamlı kuramları yalnızca gazeteciliğin ne olması gerektiğini inceledikleri için eleştirmektedir. Çünkü gerçekliğin nasıl göründüğünü yorumlamaya çalışmak kadar, karmaşık haber üretim sürecini olduğu gibi betimlemek de önemlidir. Bu nedenle gazeteciliği kimin yaptığı sorusu yetersizdir. Gazetecilik yalnızca editörler, gazeteciler ve kaynaklarla değil, haber odasındaki insan olmayan eyleyenlerle de bir bütün halinde düşünülmesi gereken bir pratiktir (Primo ve Zago, 2015, s. 38-39). Tüm katılımcı aktörler gazetecilik sürecinin parçası olarak görüldüğünde kapsamlı bir betimleme ile yeni tanımlar geliştirilebilecektir.

AAK belli ağlardaki çeşitli aktörlerin etkilerini betimlemeye yönelirken, genellenebilir sonuçlar verememesi, insan dışı olarak tanımlanan aktörleri oluşturan insan emeğini görmezden gelmesi ve açıklama yapmak yerine sürece dair fazla betimleyici bir yol seçmesi gibi nedenlerle eleştirilebilecektir. Ancak özellikle yapay zekanın gazetecilik pratiklerindeki artan etkisi nedeniyle, gazeteciliğin artık yalnızca gazetecilerin yaptığı bir iş olarak kabul edilemeyeceğine yönelik tartışılmalar (Kruckeberg ve Tsetsura, 2004, s. 84) daha da dikkat çekici hale gelmektedir. Bu kapsamda AAK, toplumsalın başlıca eyleyen görünmesini 
olumsuzlayarak, çoklu aktörlerin etkilerini ve bu aktörlerin anlık ilişkileri ile meydana gelen kısa süreli etkileşimleri gözlemlemede kullanışlı bir yaklaşım sunmaktadır (Primo ve Zago, 2015, s. 41).

Sonuç olarak aktör ağ kuramı, her ne kadar teknolojilerin ve insan dışı diğer tüm aktörlerin yaratılmasındaki insan emeğini göz ardı ederek, bu teknolojilerin dolaşıma sokulmasının ardındaki açık ve örtük anlamları saptamada yetersiz kalsa da, haber odalarında belli bir teknolojinin yarattığı dönüşümü aktörlerin çoğulluğu ve teknoloji-insan birlikteliği bağlamında betimlemede kullanışlı bir yaklaşımdır. Bu araştırmada da insan dışı bir aktör olarak robot gazetecilik teknolojisinin haber odası kültürüne eklemlenmesini, onunla bütünleşmesini ve haber üretim süreçlerindeki etkisini betimlemek için alandaki uzmanların görüşlerine başvurulmuştur.

\section{Araştırmanın Yöntemi ve Bulguları}

Araştırmanın bu bölümünde, robot gazeteciliğin hem mevcut çalışma pratiklerinde yarattığı dönüşümü serimlemek hem de gelecekte alanda gerçekleşecek olası gelişmelere işaret etmek amacıyla bilgisayar mühendisliği ve iletişim bilimleri alanındaki akademisyenler, gazeteciler ve yazılımcılarla görüşülmüştür. Bir veri toplama tekniği olarak derinlemesine görüşme, açık uçlu soruların sorun alanındaki kişilerin görüş, düşünce, fikir, bakış açısı ve deneyimlerini öğrenecek şekilde sorulması, yanıtların kaydedilmesi ve ilişkili ek sorularla araştırma konusunun ayrıntılı biçimde incelenmesi olarak tanımlanmaktadır (Kümbetoğlu, 2008, s. 71-82). Bu kapsamda, katılımcılara robot gazeteciliğin mevcut durumu, geleceği, haber odalarında ve meslek pratiklerinde yarattığı dönüşüm ile gazetecilik eğitimi üzerindeki potansiyel etkilerine ilişkin sorular yöneltilmiştir. Görüşmeler yarı yapılandırılmış sorulardan oluşan bir form ile Temmuz 2016-Aralık 2016 tarihleri arasında yüz yüze gerçekleştirilmiştir. Dijital olarak kayıtlanarak kelimesi kelimesine deşifre edilmiştir. Görüşme süreleri 30 dakika ile 1 saat arasında değişiklik göstermiştir.

Tablo 2: Görüşme Yapılan Profesyonellere Ilişkin Bilgiler

(Alfabetik olarak sıralanmıştır)

\begin{tabular}{|l|l|}
\hline Adı-Soyadı & Çalışma Alanı ve Kurum \\
\hline Öğr. Gör. Bager AKBAY & Kadir Has Üniversitesi / Robot Şair Deniz Yılmaz'ın YaratıcıSı \\
\hline Prof. Dr. Cem SAY & Boğaziçi Üniversitesi Bilgisayar Mühendisliği Bölümü \\
\hline Doç. Dr. Erkan SAKA & Bilgi Üniversitesi İletişim Fakültesi \\
\hline H. Kerem FINDIK & Digital Age Dergisi Editörü \\
\hline Hakan KARA & Cumhuriyet Gazetesi Teknoloji Yazarı \\
\hline Öğr. Gör. İsmail Hakkı POLAT & $\begin{array}{l}\text { Kadir Has Üniversitesi Yeni Medya Bölümü / } \\
\text { Elektrik-Elektronik Mühendisi }\end{array}$ \\
\hline
\end{tabular}




\begin{tabular}{|l|l|}
\hline Mustafa KULELi & $\begin{array}{l}\text { Journo Yayın Yönetmeni / Türkiye Gazeteciler Sendikası Genel } \\
\text { Sekreteri }\end{array}$ \\
\hline Prof. Dr. Tunga GÜNGÖR & Boğaziçi Üniversitesi Bilgisayar Mühendisliği Bölümü \\
\hline Doç. Dr. Zeynep ÖZARSLAN & Nişantaşı Üniversitesi Yeni Medya Bölümü \\
\hline
\end{tabular}

Tablo 2'de görüşülen kişilerin çalışma alanları ve görev aldıkları kurumlara ilişkin bilgiler yer almaktadır. Araştırmada daha önce konuyla ilgili literatürdeki çalışmaların örneklemlerinden farklı olarak, yalnızca medya profesyonelleriyle görüşülmemiş, yeni medya teknolojileri konusunda bilgi ve deneyim sahibi akademisyen ve yazılımcılara da ulaşılmıştır. Böylece, robot gazetecilik kavramının algoritmaları oluşturanlar, meslek pratiklerinde kullananlar ve konu üzerinde farklı disiplinlerde çalışanlar tarafından bütünlüklü bir biçimde tartışılabilmesi amaçlanmıştır. Görüşülen profesyonellerin mesleki kimliklerindeki çoğulluk; bilgisayar mühendisliği, programcılık, tasarım ve iletişim bilimleri alanlarının yakınsamasını göstermesi açısından da dikkate değerdir.

Araştırmacı, konu ile ilgili teknik bilgileri daha rahat sorabilmek için, 2016 yılı Linux Yaz Kampı'nda Web Önyüz (Front-End) Programlama Kursu'na katılarak, kod yazımı konusunda temel becerilerini geliştirmiş; Html, Css ve JavaScript kullanarak basit düzeyde otomatik bir hava durumu haber sayfası oluşturmuştur. Alan araştırmasından elde edilen veriler, görüşmelerde öne çıkan başlıklar altında kategorileştirilerek, aşağıda tartışılmıştır.

\section{Mevcut Durum}

Robot gazetecilik olgusu Türkiye'de ana damar medya kuruluşlarının haber odalarına seçim, hava durumu ve spor gibi nicel veri ağırlıklı haberlerle girmiş durumdadır. Alternatif ve küçük ölçekli kurumlar ise, yazılım bilgisine sahip istihdama yer açmadaki ekonomik güçlükler nedeniyle geleneksel habercilik faaliyetlerini sürdürmektedir. Haber odalarında otomatik içeriklerin çalışma mantığı bir katııımcı tarafından şöyle açıklanmıştır:

Hakan KARA: "Diyorsunuz ki yazılıma, 'Sen 30 saniyede bir şu sayfalara gir, şu verileri kontrol et.' Örneğin deprem olduğu zaman yazılım Kandilli Rasathanesi'nden verileri çekiyor ve şablon olarak haberi şöyle yazıyor: 'Saat 14.30 'da İstanbul'da meydana gelen 4.6 şiddettindeki deprem heyecan yarattı.' Diyelim ki daha büyük oldu deprem, şablona 'can kaybından endişe ediliyor' ifadesini eklersiniz. Standart metinler hazırlıyoruz. Evet, o işi yapan arkadaşlar işinden oldu. ... Bir bot çok hızlı çalışır. Dolayısıyla, tek bir tuşla, Türkiye'deki tüm illeri analiz edebilir. 'Bugün Türkiye'deki dört ilde hava sıcaklıklarında rekor yaşanacak' sonucunun hemen söyleyebilir."

Aynı katılımcı Türkiye'de robot gazetecilik olgusunun henüz yaygınlık kazanmama nedenlerini ise şöyle açıklamıştır: 
Hakan KARA: "Türkiye'de çok fazla kullanmıyorlar, tembellikten ötürü. Aslında orta seviyede bir yazılımcı bunu hazırlayabilir. Dahiyane bir yazılım meselesi değildir. Hava durumu için bir yazılım yazmak iki ya da üç günümü alır en fazla. Bu işle çok fazla ilgilenmeyenler 'vay olağanüstü' diyorlar."

Otomatize haber içeriklerinin "gazetecilik" olarak nitelendirilip nitelendirilemeyeceği tartışma konusu olmaktadır. Rutin haber metinlerinin zaten gazetecilik becerisi gerektirmediği katılımcılar tarafından sıklıkla tekrarlanmıştır.

İsmail Hakkı POLAT: "Kamu vicdanı ve kamu adına sorgulama gibi etik tavrı olan, mekanik değil duygusal nesnellikle yaklaşabilen bir otomatik gazetecilik olabileceğini düşünmüyorum. Büyük bir skandalı, yolsuzluğu ortaya çıkarma... Bunları nasıl yapacak? En azından şu andaki yapamaz, daha çok vakit var. 'Seçimlerde şu sonuç çıkarsa şöyle başlık at' demek aslında yalnızca kural seti. Tam olarak gazetecilik olarak tanımlayamayız."

Mustafa KULELi: “Bütün gazeteciler araştırmacı gazeteci değildi Türkiye'de. Parlamento muhabirliği çoğu kez mikrofon uzatıp dinlemekten ibaretti. Hepsi işsiz kalacak. İşsiz de kalsınlar zaten. Yazdığın haber, 'altını çizdi, açıkladı, belirtti, konuştu, ifade etti' şeklinde ise kork! Çünkü bunu yapmak için gazeteci olmana gerek yok. Sonuçta sesi yazıya çevirme akıllı telefonunda bile var artık. Cumhurbaşkanı konuşurken anında yazıya çevrilebilir. Yeni papa seçildiği zaman ben Vatikan'daydım. Katolikler toplanmıştı Dom'un önüne. Bekleyen herhangi bir vatandaş 'Yeni papa Fransız oldu' diye fotoğrafını çekip atabilir. O haberi ilk veren de olabilir. Bunu robotlardan önce yurttaşlar yapıyor zaten. Reuters şu an haber daha olurken fark eden algoritma yazdı. Gazeteci ne yapacak peki? Papa'nın Alman olması ile Fransız olması arasındaki fark... Bunu bilmek başka bir level."

Bager AKBAY: "Gazetecilik kendi özüne dönüyor. Gazetecilik zaten robotun yaptığı şey olmamalı. Hatta şey deriz: 'Adama bak robot gibi gazetecilik yapıyor.' Tekrar eden iş... Bir şey o kadar objektif olduğunda haber olmuyor, araç oluyor. Aracı oluyor. Rasathane datasını alıp haberleştiren yazııımı 20 dakikada yaparız. Hiçbir numarası yok. ... Mesela her resim yapabilen sanatçı mı oluyor. Yani o teknolojinin tekniği ile değil, onu nasıl kullandığım, onu nasıl anlamlandırdığım, ne anlattığım ve nasıl iletişim kurduğumla sanatçı oluyorum. Robotun o tekniğe hakim olması da gazeteci yapmıyor onu."

Haberde insani unsurlar ve duyguların eksikliğinin okuru haberden koparacağı düşünülmektedir. Bir katılımcı Türkiye'de yalnızca nesnel enformasyona dayalı rutin haberlerden oluşan bir robot gazeteciliğin okurlar tarafından rağbet görmeyeceğini belirtmiştir. Dünyanın farklı bölgelerindeki okurların haberden beklentisinin aynı olamayacağını şu sözlerle ifade etmiştir:

Erkan SAKA: "Türkiye'de tamamen enformasyon tabanlı bir gazetecilik zaten tutmaz. Bizim için gündemde bile olmayacak bir sorun robot gazetecilik. İşte finans ve hava durumu gibi alanlarda yalnızca. Aslında Amerikan gazetecilik geleneği darbeyi yiyiyor olabilir. Çünkü onlardaki bu objektivizm baskısı yorumu bitiriyor. Robotlaşma dolayısıyla Amerika'da daha da hızlı olabilir. Ama mesela Avrupa gazeteciliği her zaman daha yorum ağırlıklı ve edebi bir dilin de meşhur 
olduğu bir şeydir. Bu durumda robotlaşma bana Avrupa'da sınırlı kalacak gibi geliyor."

Yazııı konusunda uzmanlaşmış katılımcılar ise, bugün için yalnızca rutin haberlerin otomatikleştiğini, gelecekte ise insani yetenekler gerektirdiğini düşündüğümüz köşe yazısı gibi türlerin de yazılımlar tarafından yazılabileceğini belirtmişlerdir. Bir başka anlatımla, şu an için yalnızca nicel verilere dayalı şablon haberler üreten algoritmalar, gelecekte yorum ve analiz kabiliyeti kazanabilecektir.

Cem SAY: "Gazeteci olunmaz gazeteci doğulur... Yok hiçbir şey öyle değil. Insanların öğrenebildiği, bir sisteme göre çalışan ve detaylı düşünüp 'bu iş böyle yapılıyor' diye bir başkasına öğretebilecek kadar sistematize edebileceğiniz ve flow chart'a dökebileceğiniz her şeyin yazılımı yapılabilir. Bir 'Yılmaz Özdil programı yazdırmak istiyorum' diye bizim bilgisayar mühendisliğindeki program yeteneği olan çocuklar arasında bir dolaşın derim. Demek ki sizin işinizin de bir otomatik tarafı varmış. Röportaj bir gömlek zor hale getirir işi. Interaction (etkileşim) zor ama o da imkansız değil."

Tunga GÜNGÖR: "Robot insanı geçebilir ve daha iyi haber yazabilir. Bugün için klişelere bağlı yazıyor. Hatta bazen sizin unuttuğunuz geçmiş bir haberdeki ayrıntıyı arama motorlarından veri çekerek ekleyebilir. Hız avantajı var ve yazılımlar aynı anda çok fazla datayı tarayabiliyor. Insanların ise muhakeme ve duygu yeteneği avantajı var şu anda. Teknoloji çok yaratıcı metinler üretme seviyesinde değil. Ama ileride mutlaka olacaktır. Köşe yazısı yazar mı? Yazacaktır. Uzak gelecekten kastettiğim 30 yıl..."

Bager AKBAY: "Kolombiya'da Coca-Cola fiyatları arttığı için İngiltere'de deprem olduğunu bilebilecek hale gelecek algoritma. Zaman gerek. O zaman büyülenmeye başlayacağız."

Görüldüğü üzere, Türkiye'de robot gazetecilik olgusu halen bebeklik dönemini geçirmekte olup, genellikle nicel veriye dayalı rutin haberlerin otomatikleştirilmesi şeklinde gerçekleştirilmektedir. Ilerleyen yıllar içinde ise, yorum ve analiz kabiliyeti gösteren algoritmaların üretilebileceğine dair öngörüler bulunmaktadır.

\section{Haber Odasında Değişim}

Akıllı yazılımların haber odasında ne tür değişim ve dönüşümlere neden olabileceği dikkate değer bir konudur. Hangi haber türlerinin bu gelişmelerden daha fazla etkileneceği, haber odalarında nasıl bir çalışma pratiğinin geliştirilebileceği, habercilikte otomasyonun ne tür sonuçları olacağı ve gazetecileri bekleyen yeni görev tanımlarının neler olduğu bu başlık altında incelenmiştir.

Bazı katıımcılar, rutin görevlerdeki otomatikleşmeye karşın gazetecilerin yeni bazı görev tanımları olduğunu, iş gücünün başka alanlara kaydığını ancak ortadan kalkmadığını düşünmektedir. Yeni iş tanımları gazeteciyi monoton iş pratiklerinden uzaklaştırarak, iş tatminini de arttıracaktır. 
Tunga GÜNGÖR: "Şöyle bir analoji yapabilirim. Makineler artık tercüme yapıyor. Teknik tercümelerde çok iyi mesela makineler. Çünkü daha standart bir metin. 'Insanlar artık daha zevkli, edebi tercümeleri yapsın' tartışması var. Sıkıcı ve standart işleri makineler yapsın deniyor. Yani aslında iş yükü azalmıyor başka alana kayıyor. Insanlar da daha mutlu oluyor yaptıkları işten."

Zeynep ÖZARSLAN: “İnternet aynı zamanda çöplük. Dolayısıyla verinin ayıklanması gerekiyor. Veri doğrulama ve temizleme yeni iş kolları olarak önem kazanacak. Yeni iş yükleri de geliyor gazeteciye."

Mustafa KULELi: "Robotun yapamayacağı, derinlemesine analiz içeren, olayları tarihsel bağlam içerisinde veren, yorum ve analiz katan, veri görselleştiren, factchecking gerektiren hallerde veriyi doğrulayan bir hale sokacak biziz. Aslında hammaliyeden kurtulup kaliteli gazeteciliğe daha fazla vaktimiz kalacak. Mutfak robotu çıktı ama yetenekli aşçılar işsiz kalmadı. Yetenekli aşçı tam tersi vakit kazanıp yeteneğini arttırdı. Ama sen mutfakta sadece salatalık kesen adamsan evet, işsiz kalacaksın."

Robot gazetecilik günlük haber ağırlıklı yayın yapan çevrimiçi gazeteciler için tehditken, sayıları her geçen gün azalan dergilerde çalışan gazeteciler ise, otomasyondan kaynaklanan baskıyı henüz hissetmemektedir. Bir katılımcı, robot gazeteciliğin araştırma dosyaları ile habercilik faaliyetlerini sürdüren dergileri etkilemeyeceğini düşünmektedir.

H. Kerem FINDIK: “Dergi haberciliğini pek etkilemez. Robot gazetecilik bizim için dergide sadece bir dosya konusu."

Bir diğer katılımcı ise robot gazeteciliğin büyük veriden beslenmesi sebebiyle yerel gazetecilik pratiklerinde başarılı olamayacağını, bu nedenle yerel haberlerin yeniden değer kazanacağını ifade etmiştir:

Bager AKBAY: "Büyük veri lokali çok iyi anlayamaz. Lokal gazetecilik zaten günümüzde çok değerli. Bu Türkiye'de tamamen unutulmuş durumda. Şimdi fanzinler tekrar çıkmaya başladı. Zaten oraya doğru bir dönüş artıyor. Sen haber yaparken çevrendekilerle ilgili bir bilgive sahipsin. Özel bir verin var yani."

Haberlerin standartlaşarak kendini tekrar edecek olacağına dair endişelerini sıralayan bir katılımcı ise, haber odalarının arz-talep döngüsü içerisinde sık tıklanan türleri haberleştirme eğiliminde olacağını belirtmiştir. Bu görüş, okur ne istiyorsa onun otomatik olarak saptanıp, arza göre haber oluşturulacak olmasını olumlu olarak niteleyen görüşlere eleştirel bir cevap niteliğindedir:

Zeynep ÖZARSLAN: "Ford'un seri üretime geçmesi bunu önceleyen safalar olarak düşünülebilir. Robot gazetecilikte haberler gayet standart bir biçimde üretilecek. Bu standardizasyon sonucunda, tıpkı kitle endüstrisi gibi, kitle üretimi gibi haberlerin de arz-talebe göre ayarlanmasını göreceğiz. Çünkü üretim bandı da hem hızı hem verimliliği arttırmak için çıkmıştı. Çok tıklanan türler ya da yazılımlar daha fazla tekrar ederse gazetecilik kendi kendini tekrar edecektir. Entelektüel ve kültürel ilerlemeye engel olacak." 
Gazetecilik ve bilgisayar mühendisliği giderek yakınsamakta ve profesyonel rutin görevler otomatikleştirilirken yaratıcıık, analitik beceri ve kişilik daha da önem kazanmaktadır (van Dallen, 2012, s. 648-649). Haber odasında gazetecilerin bir yandan tasarımcı ve yazılımcılarla paslaşarak iş görmeleri, öte yandan ise akıllı yazılımlarla çalışmaya alışmaları gerekmektedir. Yalnızca geleneksel gazetecilik yeteneklerinin yeterli olmadığı, daha karmaşık ve disiplinlerarası bir çalışma pratiğinin haber odalarına hakim olacağı hem bilgisayar mühendisliği hem de iletişim bilimleri alanından araştırmacılarca desteklenen bir görüş olmuştur.

Erkan SAKA: "İnterdisipliner olmak lazım. Yazılımcı da gazeteciliği bilmeden bir yere kadar gelir. Adam çok iyi bir haber algoritması yapabilir ama onu haber yapacak olan gazeteciye de hep ihtiyaç var. Aslında iletişimciler yazılımcılarla iletişim halinde olup bir şey üretmeli. Yazılımı bizzat yaratan biz değiliz. Biz nasıl olacağı konusunda fikir verebiliriz."

Tunga GÜNGÖR: "Haber odasında yazııım kısmıyla muhabirlik kısmı yakınlaşıyor galiba. Yaptığı işin muhatabına yakın olmak yazılımcının işini de kolaylaştıır."

Halihazırda gazetecilerin haber odalarında yazılımcılarla çalışma ve bazen de çatışma içerisinde oldukları medya profesyonelleri tarafından da doğrulanmıştır.

\begin{abstract}
Hakan KARA: "Milyon dolar alan dâhiyane adamların bazen ciddi ölçüde kültürel eksikliğe sahip olduğunu görüyoruz. Yazılımcıların genel bir eğilimi vardır. Kendilerini müthiş bir konuma koyarlar. Ben de kod yazan bir sosyal bilimci olarak söylüyorum. Kendilerini tanrı gibi görüyorlar. Sen bu işin (gazeteciliğin) nasıl yapıldığını biliyor musun? Yok! O zaman bununla ilgili program yazamazsın. Çünkü bu işin nasıl yapıldığı ayrı bir know-how'dır. Bütün dünya interdisipliner bir yapıya dönüyor."
\end{abstract}

Robot gazetecilikle ilgili çalışmalarda "makineye karşı insan" metaforu sıklıkla karşılaştığımız bir ikiliktir (van Dallen, 2012, s. 652). Oysa gazetecilerin yazılımcılarla ortak iş yapış pratiklerine sahip oldukları gibi akıllı yazıımlarla yani robot gazetecilikle de uyumlu bir çalışma pratiği geliştirmesi beklenmektedir. "Makine ile insan" anlayışı, bu ikiliği yenerek alternatif bir kavrayış geliştirmek açısından önemlidir. Cyborg gazetecilik olarak adlandırabileceğiz bu gazetecilik türü, özetle robota kaptırılan işlerin yasını tutmak yerine, haber odalarında onunla çalışabilecek bir anlayış geliştirmek olarak tanımlanabilecektir. Teknolojiye karşı ve teknolojiye rağmen görevlerini sürdüren insan gazetecilerin mesleklerini kaybedecekleri, teknoloji ile birlikte çalışabilen cyborg gazetecilerin ise robot gazeteciliğe karşı başarılı olacağı görüşü katıımcılar tarafından şöyle açıklanmıştır:

Bager AKBAY: "Gazeteci 'robot benim işimi mi alacak?' demek yerine robotun işvereni olmalı. Robot insanı yener. Ama robot ile çalışan insanı yenen bir robot henüz yok. "

1 Cyborg sözcügü metin boyunca Donna Haraway'in (1991) insan ve makine arasındaki sınıları bulanıklaştıran, et ve metal ikiliğini yıkan, sosyal ve kurgusal olarak yaratılmış cinsiyetsiz varlık olarak betimlediği anlamıyla kullanılmıştır. 
Hakan KARA: "Robotlarla birlikte çalışmaya alışmalıyız."

Robotların gazeteciliğin haber odalarında yarattığı tehlikeyi görmek, sektörün daha fazla kâr, daha hızlı habercilik baskısını ortadan kaldırmamaktadır. Ne yalnızca insanların ne de robotların tek başlarına yapamadıkları nitelikli habercilik, robotlarla çalışan cyborg gazetecilerin yaygınlaşmasıyla sağlanabilecektir. Bu kapsamda haber odalarının hedefi, akıllı yazılımların insan gazetecileri ortadan kaldırmasını seyretmek yerine gazetecinin akıllı yazılımlarla güçlendirilmesini desteklemek olmalıdır.

\title{
Yeni İş Tanımları ve Habercilik Türleri
}

Gazetecilerin profesyonel rutin görevleri otomatikleştikçe, yaratıcılık ve analitik yetenekler gibi insana özgü özellikler ile derinlemesine analiz, röportaj ve araştırmacı gazetecilik gibi türlerin ön plana çıkacağı öngörülmektedir (Graefe, 2016). Otomatize haberciliğin yeni anlatı türlerinin çıkması için bir avantaj olarak görülmesi gerektiğini düşünen Bager Akbay, Vladimir Propp'un (2008) masallarla ilgili çalışması ile gazetecilik araştırmaları arasında bir analoji kurmaktadır. Bahsi geçen eserde Propp (2008), olağanüstü masalların dilsel benzerliklerini ortaya koymuştur. Anlatılarda yinelenen ve sabit kalan öğeleri tespit ederek, görünüşteki çeşitlilik altında binlerce masalda ortak olan benzer işlevsel unsurları sıralamıştır. Bager Akbay'a göre masallarda olduğu gibi haber dilinde de sabit yasalar, yani tekrar eden klişe anlatılar vardır. Bunlar akıllı yazılımlar tarafından kolayca taklit edilebilmektedir.

\begin{abstract}
Bager AKBAY: "Vladimir Propp'un masalı formülize ettiğini görüp 'en büyülü anlatıdan aldığımız keyfi bozdu' diyenler var. Ben 'bundan sonra beni aynı formülle kandıramayacaklar' dedim. O zaman Alice Harikalar Diyarında benim için farklı bir kitap, masal olmaya başladı. Çünkü masallardaki klişeleri kısmen kırmıştı. Haberde de yeni anlatım teknikleri gelişecektir. Dünyadaki robot gazetecilik çalışmalarına ithafen, spekülatif olduğu için Pulitzer ödülü alan robot gazeteci de çıkacaktır. İkinciyi almak zor olabilir. Yarış orada başlasın. Çünkü teknoloji bizi bir kez şaşırtıyor. Oysa henüz 6 yaşındaki kızım Masal, beni defalarca şaşırtıyor."
\end{abstract}

Bu yeni ve şu an için sıra dışı olarak tanımlanacak analiz ağırlıkı haber türlerinin de bir süre sonra sıradanlaşacağını düşünen bir diğer katıııcı, otomasyon sürecinin eninde sonunda diğer türlere de sıçrayacağını şu sözlerle açıklamıştır:

Cem SAY: "Yeni metin türleri diyorsunuz... Onların da yazılımı yapııır. Tarihsel olarak diz, aralarındaki nedensel ilişkileri sapta... O da yapılabilir. İletişimden anlamam ama 'bilgisayar şunu yapamaz' benim uzmanlık alanım. Yapamaz diye bir şey yok. Siz yapabiliyorsanız bilgisayar da yapabilir."

Yeni türlerle birlikte yeni gazetecilik istihdam alanlarının doğması da gündeme gelmektedir. The Associated Press'in Justin Myers'ı haber otomasyon editörü olarak 2015 yılında göreve alması, bilgisayar mühendisliği ile yakınsayan 
gazetecilik pratiklerine somut bir örnek oluşturmaktadır. Justin Myers'in iş tanımında "düzenleme, otomasyon, grafik ve veri analizi konusunda tecrübeli gazeteci ve yazılımcı" ifadesi yer almaktadır.

H. Kerem FINDIK: "Yeni iş kolları çıkıyor. Gazetecilerin günlük işlerini nasıl geçirdiğini, hangi kelimeleri daha çok kullandıklarını analiz ediyor mesela Justin Myers. Otomasyon yapılacak haber konularını buluyor."

Otomasyon ile birlikte, haber odalarında farkı haber türleri ile yeni iş ve görev tanımlarının ortaya çıktığı bir döneme doğru geçildiği görülmektedir. Bu güncel gelişme mevcut geleneksel gazetecilik eğitimi üzerine düşünmemizi de gerekli kılmaktadır.

\section{Gazetecilik Eğitiminde Robot Gazetecilik}

Robot gazetecilik geliştikçe, daha fazla gazeteci yorum ve analiz yapma konularında uzmanlaşmak zorunda kalacaktır. Bu durum mezunları aynı zamanda hem başarılı birer haber yazarı ve sosyal bilim uygulayıcısı hem de sofistike veri sistemlerinin teknoloji kavrayışlı operatörleri olması gereken gazetecilik okullarına çok fazla baskı yüklemektedir. İletişim fakülteleri bu dengeyi kuramazlarsa, mezunlar rutin olarak veri toplama ve haber yapma kabiliyeti olan robotlara ve etraflarındaki gerçek-yaşam durumlarından enformasyon toplayan yurttaş gazetecilerine karşı olan çekişmeyi gittikçe artan oranda kaybedeceklerdir (Van Der Haak vd., 2012). Robot gazetecilik, gazetecilik emeğini tanımlayan temel becerilerin ve öz yeteneklerin neler olması gerektiğini sorgulamamıza neden olmaktadır. Hem sektörde çalışan profesyonel gazetecileri hem de gazetecilik öğrencilerini yeni haber odası dinamiklerine hazırlayan bir dizi kurs, atölye ve ders içeriğine intiyaç duyulmaktadır.

Bazı araştırmacılar, gazetecilerin mesleğin doğal gelişiminin bir parçası olarak iş gereksinimleri ve becerileri için gerekli teknolojik ve yapısal değişikliklere direnmek yerine kabul etmeye eğilimli olduğunu savunmaktadır (Creech ve Mendelson, 2015). Bu araştırmaya katılan bir katılımcı ise, Türkiye özelinde durumun farklı olduğunu şu sözlerle ifade etmektedir:

\footnotetext{
Mustafa KULELi: "Gazeteciler kendilerini geliştirmeye çok kapalı. Her şeyi bildiklerini düşünüyorlar. TGS akademide yeni medya eğitimi düzenliyoruz... Bir tweet attık 265 başvuru yapıldı. 230'u üniversite öğrencisiydi. Gazeteciler gelmiyor."
}

Medya profesyonelleri gelişime ayak uydurmada gönülsüz de olsa, gazetecilikteki otomasyon süreçlerinin gazetecinin yeteneklerine veri analizi, programlama ve görselleştirme becerilerinin eklenmesini gerektirdiği açıktır (Mayer-Schönberg ve Cukier, 2013). Ders programlarına bu konuları kapsayan dersler de nispeten yakın bir zamanda eklenmeye başlamıştır (Thurman vd., 2017, s. 2). Dünya üniversitelerinde, gazeteciler için programlama dili ile ilgili 
ders içeriklerinde genellikle HTML, CSS ve JavaScript betik dili öğretilmektedir. Katılımcılara Türkiye'de gazeteciler için kod derslerinin içeriğinin nasıl olması gerektiği sorulduğunda, şu yanıtlar alınmıştır:

Erkan SAKA: "Bir miktar kodlamadan haberi olması lazım gazetecilik öğrencisinin. Bir iletişimcinin o altyapıyı bilmesi lazım ama nereye kadar sorusu var. Bir giriş dersi olabilir. En basitinden bloggerlık bile yaparken css kodlarını biliyorsan, birkaç şeyi düzeltebiliyorsun."

Tunga GÜNGÖR: "Kod yazmaktan ziyade ya da ona ek olarak o ișin mantığını ya da nasıl ilerlediğini öğrenmek, bilmek gerek belki... Gazetecilerin yazılımcıların ne yaptığını bilmeleri, çok kod yazamalasalar da algoritma mantığını anlamaları gerekir. Bu durum, ne isteyeceklerini bilmelerini sağlar. İletişimi kolaylaştırır. Hangi programları öğrensinler? Bugün JavaScript yarın başka bir şey. Değişecektir."

Cem SAY: "Mevzu HTML, CSS ve JavaScript öğrenin değil. Hangi programlama dillerini mi öğrensinler? Bu eski bir soru. Bir tane öğrenseler yeter. Programlamayı öğrensinler. Nasılsa üç sene sonra onun yenisi çıkacak. İşsizlik oranı fazlaysa akademide onu respond edecek (cevap verecek) bir mekanizma bulmanız lazım."

Bager AKBAY: "Bence gazeteciler için HTML, CSS ve JavaScript olmaz. Veri madenciliği için Pyton ile başlayabilirler. Ama mesela şu anda Snap öne geçmeye başladı. Önemli olan gazetecilik öğrencisinin dijital medyaokuryazarı ve medya üreticisi olması. HTML filan kalmadı. Çocuğa Wordpress kurmayı öğret geç. Veri çekip görselleştirmek için Joy of Computing'i takip edebilirler. Akademisyen olacaksa da öğrenecek. Veri işlemeyen akademisyen olamaz artık. Illkokul ikiye bile öğretiyoruz."

Medya profesyoneli olan bir katılımcı, haber odalarındaki ihtiyaca yönelik yeni eğitim anlayışının gerekliliğini açıklarken, bunun neden elzem olduğunu Panama Belgeleri olayı üzerinden açıklamıştır.

Mustafa KULELi: “Eğer bir gazetecilik eğitimi olacaksa kod, veri analizi, factchecking'e yönelmeli. Gazetecinin not defterini alıp Genelkurmay'a gitmesinden söz etmiyorum. Server kurabilecek... Panama belgeleri yayımlandı. Türkiye'nin anlı şanlı gazetelerinde çıkan haber şuydu: "Belgelerde şunun adı geçiyor." Bu nasıl habercilik? Kayıtlara göre 25 bin gazeteci var. Sadece bir kişi server kurup veriyi indirdi ve tasnif edebildi. Hangi gazeteciliğin anlamlı olduğu ortaya çıkıyor. Gazeteciler bırak veriyi server'a koyup analiz edip anlamlı sonuç çıkarmayı, Excel bile kullanamıyor."

Gazetecilerin ve gazetecilik öğrencilerinin teknolojiye teslim olmak yerine, onu etkili bir biçimde kullanmaları gerekmektedir. Çünkü her ne kadar robot-insan karşılaştırmasında çoğunlukla robotlar kazansa da, robota karşı robot ile birlikte çalışan insan her zaman öndedir. Bu durum teknolojiyi kullanan ve üreten cyborg gazetecilere duyulan intiyacı ortaya koymaktadır. Bir katıımcı bu durumu şöyle özetlemiştir: 
Bager AKBAY: "Dünyanın en iyi satranç programı insanı yenebiliyor değil mi? Peki ben insan olarak bu otomatik satranç yazılımını yanıma alsam, karşıma da yalnızca robotu koysam kim yener? Yani eğer program ortalama hamle sayısını 10'a düşürüp insana gösterirse, insan robotu yeniyor. Cyborg ile robotun yarışması budur. Cyborg hala kazanıyor. Daha çok uzun süre cyborg kazanacak. Önümüzdeki 30-40 yıl robotların değil, cyborların yılı. Çocukların neden programlama öğrenmesi gerekiyor? Cyborg olabilmesi için. Robotlar senin rutin işlerini yapsın. Onlar senin vezirlerin, işçilerin, askerlerin olsun. Kararları sen ver! Wikileaks fikrini hâla robot bulamaz. İşte o bir pradigma değişikliğidir."

Robot gazetecilik eğitiminin yalnızca teknolojik boyutu bulunmamakta, aynı zamanda algoritmaların yaratabileceği yanlılığa dair farkındalık yaratması da gerekmektedir. Bu kapsamda, robot gazetecilik etiği ayrı bir başık altında değerlendirilmiştir.

\section{Robot Gazetecilik ve Etik}

Gazetecilikteki otomasyonun daha nesnel ve hatasız bir habercilik getireceğine dair yaygın bir inanış olsa da, algoritmalarla manipülasyon yapılabileceğine dair araştırmalar (Diakopoulos ve Koliska, 2016; Thurman vd., 2017; Kent, 2015) bu çalışmanın literatür kısmında da incelendiği gibi gündeme gelmeye başlamıştır. Görüşmelerde ise etik meselesinin robota özgü olmadığı, insan gazetecilerin de çok sık etik ihlaller yaptıkları vurgulanarak, medya okuryazarlığının önemine işaret edilmiştir.

Mustafe KULELI: “İnsan gazeteciler hata yapmıyor mu? O da kaynağa baksa aynı veriyi görecek."

İsmail Hakkı POLAT: "İnsan gazetecilerimiz de etik inlaller yapıyor. Robotun üzerine attığımız şeyler zaten basında oluyor. Önemli olan kullanıcının okuryazarlık kazanması."

Bager AKBAY: "Robotun yaptığı etik sorunları insan gazeteci yapmıyor muydu? Yapıyordu. Tepkiler o kadar fazla oluyor ki robot daha kolay gelişiyor. Yanlış haber yapan gazeteciyi atarsın, algoritmayı update edersin."

Her şeyden önce algoritmaların veriyi çektiği kaynaklar hata verebilmekte, hacklenebilmektedir. Örneğin bir borsa haberinde, herhangi bir hisse senedine ilişkin verinin yanlış bir kaynaktan çekilmesi sonucunda binlerce insan yatırımlarını değiştirme yoluna gidebilecektir.

Bager AKBAY: "Robot haber yaptı diyelim. 'Muhtemelen yarın dolar \% 3 artacak' dedi. Daha önceki Trump'ın açıklamalarına bakarak benzerliklerden yola çıkarak dolar artacak dedi. Finansal tahmin çok riskli bir iştir. Çünkü tahmini yapmak bile tahmini değiştirir. 'Bilgisayara neden bu tahmini yaptın bize bunu basitçe açıkla' diyemiyoruz. İnsan aklı şöyle çalışıyor. Bir sezgilerin var bir de reasoning var. Bilgisayar seziyor ama reasoning henüz yok." 
Algoritmik saydamlık konusunda kullanııların ne beklediğine ilişkin ise çok az şey bilinmektedir. "Kullanıcılar algoritmanın nasıl işlediğini anlamaya intiyaç duyuyor ya da istiyorlar mı?" sorusunun yanıtına dair alanda yapılmış güçlü bir araştırma bulunmamaktadır (Graefe, 2016). Algoritmanın yaptığı bir hatadan kimin ya da kimlerin sorumlu tutulacağı ise belirsizliğini korumaktadır. Algoritmalar tarafından oluşturulmuş hatalı bir otomatik haberin sorumlusu genel yayın yönetmeni mi, yazıımcı mı, editörler mi olacaktır?

\footnotetext{
Erkan SAKA: "Yayıncı genel olarak sorumludur zaten enformasyondan ama bunu kendi içlerinde nasıl halledip çözerler bilemiyoruz. Tek bir aktör de suçlu olmayabilir. Yani birtakım yönetmelikler değişecek. Dinamik bir biçimde buna kafa yormalıyız."
}

Yazııımcıların yalnızca teknik yapılabilirlik üzerinde durduğunu, toplumsal ve etik boyutları ise göz ardı ettiklerini düşünen bir katıımcı, bu fikrini güncel ve çarpıcı bir örnek üzerinden şöyle açıklamıştır:

\begin{abstract}
Hakan KARA: "Microsoft adını Tay koyduğu bir akıllı yazılımı Twitter'dan Internete açtı. Fakat Tay ırkçı söylemler kullanmaya başladı. Bir grup insan örgütlenip İnternet üzerinden robotla konuşmaya başladılar. Hitler'i öğretmesini sağladılar mesela. Kadınlara ilişkin olmadık laflar... Nefret söylemi... Bunu da çok kısa bir sürede 48 saatte başardılar. Sonuçta kapatmak zorunda kaldılar botu. Yapay zekayı saf bir çocuk olarak ortaya atamazsınız. Insanlığın çağdaş değerlerini öğretmek zorundasınız. Isaak Asimov'un 1940'larda yazdığı Robot Yasaları üzerine düşünülemez mi? Robot etiği üzerine 2004 yılında Sanremoıda yapılan uluslararası toplantının notları gözden geçirilemez mi? Çünkü ileride basit bir 'pardon' yetmeyebilir."
\end{abstract}

Görüldüğü üzere, algoritmalar tarafından yazılan otomatik haberlerin, yalnızca haber odalarına giren yeni bir teknoloji olarak değerlendirilmesi sorunludur. Otomatize içeriğin neden olduğu etik sorunlar resmi kaynaklara olan bağımlııı, abartıı nesnellik iddiası, filtreleme, mahremiyet, gizlilik ve güvenlik konularını da içerecek şekilde değerlendirilmelidir.

\title{
Sonuç
}

Haber üretim süreci gazeteciler, yöneticiler, teknisyenler, örgütsel yapılar, içerik yönetim sistemi, sayfa tasarım programları/yazılımları, kılavuzlar ve otomatik haber yazılımları gibi çok sayıda aktörün varlığı ve birbirleriyle etkileşiminin sonucudur (Kumar ve Haneef, 2016, s. 118; Hemmingway, 2007). $\mathrm{Bu}$ araştırmada heterojen bir ağ olarak kabul edilen haber odalarında, yeni bir aktör olarak karşımıza çıkan otomatik haber içeriklerinin haber üretim sürecindeki işlevi uzman görüşleri ile tartışmaya açılmıştır. Araştırmada örgütsel, söylemsel, kişiler arası ya da teknolojik bir odak belirlenmemiş, bunun yerine otomatik haber içeriklerinin haber üretim sürecindeki rolü aktör ağ kuramı bağlamında teknolojiinsan birlikteliğini gerektiren dönüştürücü potansiyeli ekseninde betimlenmiştir. 
Yapılandırılmış verilerden otomatik haber üreten algoritmalar gazetecilik endüstrisini dönüştürmektedir. Robot gazetecilik olarak adlandırılan bu gelişmenin en çarpıcı etkisi, rutin habercilik faaliyetleri ile uğraşan gazetecilerin karşı karşıya kalacakları işsizliktir. Ancak insan emeğine duyulan intiyaçtaki azalma yalnızca robot gazeteciliğin neden olduğu bir olgu olarak değerlendirilemez. Robot gazetecilik kısa süreli sözleşmeler, serbest çalışmanın (freelance) yaygınlaşması ve dış kaynak kullanımı (outsourcing) gibi gelişmelerden bağımsız değil, bizatihi bu gelişmeleri besleyen ve onlarla kesişen bir teknolojik gelişmedir.

Uzman görüşlerinden hareketle, kişiselleştirme özelliklerinin eklenmesiyle daha da gelişecek olan otomatik haber yazılımları, rutin haber toplama ve yazma pratiklerinde çarpıcı ve köklü bir değişikliklere neden olacaktır. Ancak haber üretim sürecindeki otomatikleşmenin röportaj, haber analizi ve köşe yazısı gibi etkileşim ve insani unsurların ön planda olduğu türlerin üzerinde henüz etkili olamayacağı değerlendirilmektedir. Bu kapsamda, gelecekte algoritmaların ürettiği kısa ve görsel ağırlıklı ara formlara karşın, haber ve yorumu bir arada harmanlayan haber anlatılarının varlığını bir süre daha sürdüreceği öngörülmektedir. Miktarı çok verinin temizlenmesi ve doğrulanması da gazetecileri bekleyen yeni iş tanımları olarak karşımıza çıkmaktadır.

Otomatik haber yazııımları haber üretim sürecini daha karmaşık bir hale getirerek teknoloji-insan birlikteliğini gerekli kılacak bir düzeleme taşımaktadır. Bu nedenle haber odalarının yeni bir girdisi olan robot gazetecilik, hem gazetecinin öz yetenekleri hem de gazetecilik eğitimi üzerinde yeniden düşünmemizi gerekli kılmaktadır. Örneğin haber odalarında yazııımc gazetecilerin yer bulmaya başladığı, yeni bir tür eşik bekçiliğinin türediği gözlenmektedir. Bir başka anlatımla, bilgisayar mühendisliği ve iletişim bilimlerindeki yakınsamayla birlikte, kod yazabilen ve yazılım bilgisine sahip cyborg gazetecilere ihtiyaç duyulmaya başlanmıştır.

Bu kapsamda iletişim fakültelerinin ders programlarına eklenmeye başlanan gazeteciler için programlama derslerinin konunun yalnızca teknik boyutuna odaklanmaması gerekmektedir. Otomatize içeriğin nesnelliğine duyulan abartılı güven başta olmak üzere, algoritmik yanlıık, gizlilik ve mahremiyet gibi etik meselelere de ışık tutan ders içeriklerine intiyaç duyulmaktadır. 


\section{Kaynakça}

Adams, T. (28 Haziran 2015). And the Pulitzer goes to... a computer. The Guardian. Erişim 15 Mart 2017, https://www.theguardian.com/technology/2015/ jun/28/computer-writing-journalism-artificial-intelligence

Alexander, P. M. ve Silvis, E. (2014). Towards extending actor-network theory with a graphical syntax for information systems research. Information Research, 19(2).

Anderson, C. W. (2013). Towards A Sociology of Computational and Algorithmic Journalism. New Media \& Society, 15(7), 1005-1021.

Ballantyne, Neil (2015). Human Service Technology and the Theory of the Actor Network. Journal of Technology in Human Services. 33, 104-117.

Bangalore, S., Rambow, O., ve Whittaker, S. (2000). Evaluation Metrics for Generation, içinde Proceedings of the 1st International Conference on Natural Language Generation, 1-8.

Belz, A., ve Albert, G. (2008). Intrinsic vs. Extrinsic Evaluation Measures for Referring Expression Generation. içinde Proceedings of the 46th Annual Meeting of the Association for Computational Linguistics, Columbus, $\mathrm{OH}$.

Bunz, M. (2010). In the US, algorithms are already reporting the news. The Guardian. Erişim 15 Mart 2017, https://www.theguardian.com/media/pda/2010/ mar/30/digital-media-algorithms-reporting-journalism

Carlson, M. (2014). The Robotic Reporter: Automated Journalism and the Redefinition of Labor, Compositional Forms, and Journalistic Authority. Digital Journalism. 3, 416-431.

Ciampaglia, G.L.; Shiralkar, P.; Rocha, L. M.; Bollen, J.; Menczer, F.; Flammini, A. (2015). Computational fact checking from knowledge networks, Plos One, 10(10), 1-13.

Clerwall, C. (2014). Enter the Robot Journalist. Journalism Practice. 8(5), 519531.

Creech, B., ve Mendelson, A.L. (2015). Imagining the Journalist of the Future: Technological Visions of Journalism Education and Newswork. Communication Review, 18(2), 142-165.

Dawson, R. (2010). The Rise of Robot Journalists. Erişim 30 Mart 2017, http:// rossdawsonblog.com/weblog/archives/2010/04/the_rise_of_rob.html

Diakopoulos, N. ve Koliska, M. (2016). Algorithmic Transparency in the News Media. Digital Journalism, Published online: 27 Haziran 2016, 1-20.

Dörr, K. N. (2016). Mapping the Field of Algorithmic Journalism. Digital Journalism 4 (6), 700-722. 
Dudhwala, F. (2009). What is Actor-Network Theory?, Erişim 30 Ekim 2017 https://www.academia.edu/542543/What_is_Actor-Network_Theory

Ellis, J. (2013). The Guardian experiments with a robot-generated newspaper with the long good read. Nieman Lab. NiemanLab. Erişim 18 Mart 2017, http:// www.niemanlab.org/2013/12/theguardian-experiments-with-a-robot-generated newspaper-with-the-long-goodread/

Fioravanti, C. ve Velho, L. (2010). Let's follow the actors! Does Actor-Network Theory have anything to contribute to science journalism?. Journal of Science Communication. 9(4), 1-8.

Graefe, A. (2016). Guide to Automated Journalism. Tow Center For Digital Journalism. Erişim 26 Aralık 2016, http://towcenter.org/research/guide-toautomated-journalism/

Haraway, D. (1991). A Cyborg Manifesto: Science, Technology, and SocialistFeminism in the Late Twentieth Century. Simians, Cyborgs, and Women: The Reinvention of Nature, New York: Routledge, 149-181.

Hassan, N.; Adair, B.; Hamilton, J.; Li, C.; Tremayne, M.; Yang, J.; Yu, C. (2015). The Quest to Automate Fact-Checking. Computational Journalism Symposium 2015, 1-5.

He, H. (2015). End of the road for journalists? Tencent's Robot reporter 'Dreamwriter' churns out perfect 1,000-word news story in 60 seconds. In South China morning post. Retrieved from http://www.scmp.com/tech/china-tech/ article/1857196/end-road-journalists-robot-reporter-dreamwriter-chinas-tencent

Hemmingway, E. (2007). Into the Newsroom: Exploring the Digital Production of Regional Television News. London: Routledge.

Jung, J.; Song, H., Kim, Y., Im, H. ve Oh, S. (2017). Intrusion of software robots into journalism: The public's and journalists' perceptions of news written by algorithms and human journalists. Computers in Human Behavior. 71, 291-298

Karlsen, J. ve Stavelin, E. (2014). Computational Journalism in Norwegian Newsrooms. Journalism Practice, 8(1), 34-48.

Kent, T. (2015). An Ethical Checklist for Robot Journalism. Erişim 30 Mart 2017, https://medium.com/@tjrkent/an-ethical-checklist-for-robot-journalism-1f41dc bd7be2

Kumar, A. ve Haneef, M. Suhaib Mohamed (2016). Convergence of technologies and journalists: Translation of journalistic practices through ANT perspective. Estudos em Comunicação, 22, 105-122.

Kruckeberg, D. ve Tsetsura, K. (2004). International Journalism Ethics. içinde Global Journalism: Topical Issues and Media Systems, edited by Arnold S. de Beer ve John C. Merril, Boston, MA: Pearson Education, 84-92. 
Kümbetoğlu, B. (2008). Sosyolojide ve Antropolojide Niteliksel Yöntem ve Araştırma, İstanbul: Bağlam.

Latour, B. (2005). Reassembling the Social: An Introduction to Actor-networktheory. New York: Oxford University Press.

Levy, S. (2012). Can an Algorithm Write a Better News Story Than a Human Reporter?. Wired. Erişim 26 Aralık 2016, http://www.wired.com/2012/04/can-analgorithm-write-a-better-news-story-than-a-human-reporter

Lewis, Seth C. (2015). Journalism in an Era of Big Data: Cases, Concepts, and Critiques. Digital Journalism, 3(3), 321-330.

Lewis, Seth C., ve Westlund, O. (2014). Big Data and Journalism: Epistemology, Expertise, Economics, and Ethics. Digital Journalism, 1-2.

Matthews, K. (2014). 10 Reasons Why Robot Journalism Can't Stop The Real Thing. Muck Rack Daily, Erişim 15 Nisan 2017, https://muckrack.com/ daily/2014/08/19/10-reasons-why-robot-journalism-cant-top-the-real-thing/

Mayer-Schönberger, V. ve Cukier, K. (2013). Big Data: A Revolution that Will Transform How We Live, Work, and Think. London: John Murray Publishers.

Momus (29 Ağustos 2006). Robots Wrote This. Wired. Erişim 15 Temmuz 2011, http://archive.wired.com/culture/lifestyle/commentary/imomus/2006/08/71654

Oremus, W. (2014). The First News Report on the L.A. Earthquake Was Written by a Robot. Erişim 25 Mayıs 2017, http://www.slate.com/blogs/future_ tense/2014/03/17/quakebot_los_angeles_times_robot_journalist_writes_article_ on_la_earthquake.html

Plesner, U. (2009). An actor-network perspective on changing work practices. Journalism. 10(5), 604-626.

Probb, V. (2008). Masalın Biçimbilimi. Çev. Mehmet Rifat-Sema Rifat, İstanbul: Iş Bankası Kültür Yayınları.

Primo, A. ve Zago, G. (2015). Who And What Do Journalism? An actor-network perspective. Digital Journalism. 3(1), 38-52

Royal, C. (2012). The Journalist As Programmer: A Case Study of The New York Times Interactive News Technology Department. \#ISOJ The Official Research Journal of the International Symposium on Online Journalism, 2(1).

Son, J. (2016). Will robot reporters replace humans? The Korean Observer. Erişim 14 Mayıs 2017, http://www.koreaobserver.com/will-robot-reportersreplace-humans-63057/

Statsheet (2011). About Statsheet. Erişim 15 Temmuz 2011, http://statsheet. com/about 
Thurman, N.; Doerr, K. ve Kunert, J. (2017). "When Reporters Get Hand-On With Robo-Writing: Professionals Consider Automated Journalism's Capabilities and Consequences. Digital Journalism, 1-20.

Tornoe, R. (2014). Learn to Stop Worrying and Love Robot Journalists. Digital Publishing, E\&P.

Turner, Fred (2005). Actor-Neteorking the News. Social Epistemology, 19(4), 321-324.

Van Dalen, A. (2012). The Algorithms Behind the Headlines: How MachineWritten News Redefines the Core Skills of Human Journalists. Journalism Practice. 6(5-6), 648-658.

Van Deemter, K., Krahmer, E., ve Theune, M. (2005). Real vs. Template-based Natural Language Generation: A False Opposition. Computational Linguistics, 31(1), 15-23.

Van Der Haak, B., Parks, M. ve Castells, M. (2012). The Future of Journalism: Networked Journalism. International Journal of Communication. 6, 2923-2938.

Van der Kaa, H. ve Krahmer, E. (2014). Journalists Versus News Consumer: The Perceived Credibility of Machine Written News. Proceedings of Computation+Journalism Symposium 2014, 1-4

White, C. (2016). We, Robots: Staying Human in the Age of Big Data, Melville House Publishing, USA. 